Svetlana Sokolov Mladenović ${ }^{1}$

University of Niš, Faculty of Economics
ORIGINAL SCIENTIFIC ARTICLE doi: $10.5937 /$ ekonomika2003015S Received: March, 18. 2020. Accepted: May, 14. 2020

\title{
APPLICATION OF INSTITUTIONAL INNOVATION IN TRADE - EXPERIENCE OF MARKET-DEVELOPED ECONOMIES
}

\begin{abstract}
One of the main features of trade in developed market conditions is innovation. Almost no sector of the economy is so intensely prone to change and innovation as trade. For this reason, trade development experience of market economies so far is extremely rich and provides opportunities for some generalization and analysis of certain principles in the processes of development and implementation of innovation in trade. In addition, innovation in trade is markedly diverse and abundant, with institutional innovation occupying a significant place. In line with the above, the subject of this paper relates to the analysis of the application of institutional innovation in trade. The objective of the paper is to review the achieved level of institutional innovation in trade of the developed economies. Based on the available secondary data sources, we conduct an empirical study to test the hypothesis of the importance of institutional innovation for the positioning of trading companies. The ANFIS method was used to test the hypothesis. The results of the research showed that the introduction of institutional innovations influences on the positioning of trading companies.
\end{abstract}

Key words: trade, trade institutions, theories, life cycle, trading companies

JEL classification: L81, O31

\section{ПРИМЕНА ИНСТИТУЦИОНАЛНИХ ИНОВАЦИЈА У ТРГОВИНИ-ИСКУСТВА ТРЖИШНО РАЗВИЈЕНИХ ПРИВРЕДА}

\author{
Апстракт
}

\begin{abstract}
Једно од основних обележја трговине у развијеним тржишним условима јесу иновације. Скоро ни један сектор привреде није тако интензивно подложан променама и иновачијама као ито је трговина. Из тог разлога су и искуства досадашьег развоја трговине тржишно развијених привреда изузетно
\end{abstract}

\footnotetext{
${ }^{1}$ svetlana.sokolov@ekonomski.rs, ORCID ID 0000-0002-9367-4252

This paper is the result of research on obligations under the Agreement on the Implementation and Financing of the Scientific Researche in 2020 (registration number 451-03-68 / 2020-14 / 200100) concluded between the Ministry of Education, Science and Technological Development of the Republic of Serbia and the Faculty of Economics, University of Niš
} 
богата и пружају могућности за одређена уопштавања и анализу извесних законитости у процесима развоја и имплементащије иновација у трговини. При томе, уочава се и изразита разноврсност и бројност иновачија у трговине, где институционалне иновачије заузимају значајно место. Полазећи од ових чињеница, предмет истражсивања овог рада односи се на анлизу примене институционалних иновација утрговини. Циљ радајесте сагледати достигнути ниво институциионалних иноваџија у трговини тржишно развијених привреда. На бази расположсивх секундарних извора података, спроведено је емпиријско истраживање којим је тестирана хипотеза о значају институционалних иновација за позиционирање трговинских компанија. Коришћен је АНФИС метод за тестирање хипотезе. Резултати истражсивања су показали да увођење институционалних иновачија утиче на позиционирање трговинских компанија.

Кључне речи: трговина, трговинске институције, теорије, животни цииклус, трговинске компаније.

\section{Introduction}

In today's conditions, trade is increasingly becoming the epitome of a dynamic and competitive economic sector. There are numerous reasons for such qualification, as evidenced by the different results of theoretical and practical research. One of them is the permanent and intensive application of innovation in trade, which further qualifies it as an innovation-intensive economic sector. Innovation itself is the fundamental basis of economic progress, regardless of the characteristics of the socio-political system. Thus, Schumpeter (1950) says that competition through innovation is much more significant than competition through price. From this perspective, innovation greatly influences changes in the structure of trade. In doing so, innovation in trade is abundant and diverse. Authors agree that all innovation in trade, generally speaking, can be classified into institutional, functional and technological (Sokolov Mladenović \& Vukojević, 2019). Institutional innovation plays a leading role in trade, seen in the long run. It is reflected in the permanent process of market entry, development and disappearance of one group of trade institutions and the emergence of another. In doing so, trade institutions denote different organizational forms, systems, and methods of conducting trade activities. The presence of trading institutions on the market is marked by different forms of competition and market appearance of trading companies. They are mostly reflected in the development of the sales network of trading companies. Each trade institution has its own life cycle, which includes the phase of market entry, growth, saturation, decline and disappearance, or revitalization and upswing. These phases reflect institutional innovation in trade of economies with different level of socio-economic development. Given that the focus of research in this paper is institutional innovation in trade, the paper is divided into three segments. The first part of the paper analyzes the theoretical aspects of institutional innovation in trade. The second part of the paper analyzes the achieved level of institutional innovation in trade of market economies. In the third part of the paper, we conduct research to test the hypothesis of the importance of institutional innovation for positioning of trading companies. 


\section{Theoretical backgrounds of institutional innovation in trade}

Numerous theories can explain the growth and development of trade institutions. In other words, there are several concepts or theories used to scientifically explain changes in trading institutions, i.e. institutional innovation, given different stages of the life cycle they go through. Generally speaking, these theories provide a conceptual framework for understanding the evolution of trade institutions but also for defining the strategy for their further development. They can be divided into three groups (Gilbert, 2003; Morgan, 2015; Pantano et al., 2017): 1) Environmental theories, 2) Cyclic theories and 3) Conflict theories.

Environmental theories explain changes in trade as a result of changes in the wider environment, such as the crisis in the country's economy, changes in consumer lifestyles, changes in legal regulation, and the like. There are a number of factors that influence changes in trade, such as economic, political, cultural, sociological, demographic, etc. Some of these factors have a direct effect on changes in trade, such as the impact of regulation regarding the opening hours of retail outlets on market supply. On the other hand, some factors have an indirect impact on trade development, such as the employment of women that has changed consumer and purchasing habits. Environmental theories include (Picot-Coupey, Viviani \& Amadieu, 2018): macroanalytic theories, dialectical process theory, adaptive behavior and natural selection theory, and market structure and developmental stages theory.

Cyclic theories assume a scenario or pattern in the form of a cycle by which changes in trade can be predicted. This group of theories include (Reynolds et al., 2007): point-of-sale theory, drive-shape dynamics theory, retail harmonic theory, life cycle theory, and life-rhythm law.

Conflict theories assume that changes in trade arise as a result of the mutual relationship between traders, their competitive behavior and adaptation to market innovation. This group of theories includes (Hristov, 2007): mixed assortment trading theory, market gap theory, and polarization theory.

Based on the previous theories, it is possible to identify certain principles arising in the development of trade institutions so far, i.e. the principles underlying institutional innovation in trade (Hristov \& Reynolds, 2015; Pantano, 2016; Lovreta et al., 2019):

- As a rule, most developed market economies have institutional as well as other innovation in trade;

- In the less developed economies, the process of accepting institutional innovation in trade is steadily intensifying;

- The process of implementing institutional innovation in trade intensifies as a whole, to shorten the life cycle of trade institutions;

- Major trading companies dominate the process of implementing institutional innovation;

- Institutional innovation is present not only in classical but also in modern forms of trade.

Theoretically and practically speaking, institutional innovation in trade takes place in a particular social environment. It consists of three components: competitors, 
manufacturers and consumers. This environment determines the intensity of application of institutional as well as other innovation in trade. In other words, it depends on the manufacturers, consumers and competitors whether or not institutional innovation will be applied in trade. Trading companies are very often viewed as adapters, but very often as original holders of institutional innovation on the local market, which is especially evident in the process of internationalization of trade. Thus, the transfer of institutional innovation in trade between countries with different levels of market development gains in importance. By expanding their operations onto different markets, i.e. through the process of internationalization, trading companies introduce and transfer institutional innovation. Their transfer requires a certain level of economic development, a flexible trade policy, but also an appropriate level of overall education of the population. Thus, some studies have shown difficulties in transferring supermarket technology to less developed countries (Ćuzović, Sokolov Mladenović \& Ćuzović, 2019). Specifically, the supermarket technology is based on a constant and rich supply of energy, prepackaged products prepared for widespread use, on modern services and communication, but also on a wide and diversified offer of products and services. Therefore, it is understandable that the development of supermarkets faces fierce resistance from small retailers with traditional sales systems. Their strength varies by country. So, the final word on the success of institutional innovation, in addition to the level of socio-economic development, is to be given by consumers. They are in a position to accept or reject certain institutional innovation, which gives them a significant and sensitive role in the overall processes of implementing innovation in trade.

\section{The achieved level of institutional innovation in trade of market economies}

The competitive environment influences the ongoing process of institutional innovation in trade. The disappearance of one group of trade institutions and the emergence of new ones is one of the important trends in trade. This is especially pronounced through (Evans, 2011; Cao, 2014; Pantano, 2016): 1) new trading forms due to changes in consumer lifestyles, 2) shorter life cycle of trading institutions, as new trading forms reach the stage of maturity more quickly, 3) competition among different trading institutions, 4) application of modern technology in trade institutions.

An illustrative example of the ongoing process of institutional innovation in trade is the world's leading retail chains, in terms of sales volume. Based on the latest Global Power of Retailing 2019 report, one can see the dominant trading institutions or formats used by the largest trading companies in their portfolio. The ten largest trade chains and their trade formats (institutions) are presented in Table 1. 
Table 1: Top 10 trade companies, 2017.

\begin{tabular}{|c|c|c|c|c|c|c|c|}
\hline Rank & $\begin{array}{l}\text { Name of } \\
\text { company }\end{array}$ & $\begin{array}{l}\text { Country } \\
\text { of origin }\end{array}$ & $\begin{array}{l}\text { FY2017 } \\
\text { Retail } \\
\text { revenue } \\
\text { (US\$) }\end{array}$ & $\begin{array}{l}\text { FY2017 } \\
\text { Retail } \\
\text { revenue } \\
\text { growth }\end{array}$ & $\begin{array}{l}\text { Trade institutions } \\
\text { (formats) }\end{array}$ & $\begin{array}{l}\text { Countries } \\
\text { of } \\
\text { operation }\end{array}$ & $\begin{array}{l}\% \text { Retail } \\
\text { revenue } \\
\text { from foreign } \\
\text { operations }\end{array}$ \\
\hline 1 & $\begin{array}{l}\text { Wal-Mart } \\
\text { Stores, Inc. }\end{array}$ & US & 500.343 & $3,0 \%$ & $\begin{array}{l}\text { Hypermarket/ } \\
\text { Supercenter/ } \\
\text { Superstore }\end{array}$ & 29 & $23,9 \%$ \\
\hline 2 & $\begin{array}{l}\text { Costco } \\
\text { Wholesale } \\
\text { Corporation }\end{array}$ & US & 129.025 & $8,7 \%$ & $\begin{array}{l}\text { Cash \& Carry/ } \\
\text { Warehouse Club }\end{array}$ & 12 & $27,2 \%$ \\
\hline 3 & $\begin{array}{l}\text { The Kroger } \\
\text { Co. }\end{array}$ & US & 118.982 & $3,2 \%$ & Supermarket & 1 & $0,0 \%$ \\
\hline 4 & $\begin{array}{l}\text { Amazon. } \\
\text { com, Inc. }\end{array}$ & US & 118.573 & $25,3 \%$ & Non-store & 14 & $36,8 \%$ \\
\hline 5 & $\begin{array}{l}\text { Schwarz } \\
\text { Group }\end{array}$ & Germany & 111.766 & $7,4 \%$ & Discount store & 30 & $58,9 \%$ \\
\hline 6 & $\begin{array}{l}\text { The Home } \\
\text { Depot, Inc. }\end{array}$ & US & 100.904 & $6,7 \%$ & $\begin{array}{l}\text { Home } \\
\text { Improvement }\end{array}$ & 4 & $8,4 \%$ \\
\hline 7 & $\begin{array}{l}\text { Walgreens } \\
\text { Boots } \\
\text { Alliance, Inc. }\end{array}$ & US & 99.115 & $2,1 \%$ & $\begin{array}{l}\text { Drug Store/ } \\
\text { Pharmacy }\end{array}$ & 10 & $11,9 \%$ \\
\hline 8 & $\begin{array}{l}\text { Aldi Einkauf } \\
\text { GmbH \& } \\
\text { Co. oHG }\end{array}$ & Germany & 98.287 & $7,7 \%$ & Discount store & 18 & $65,1 \%$ \\
\hline 9 & $\begin{array}{l}\text { CVS Health } \\
\text { Corporation }\end{array}$ & US & 79.398 & $-2,1 \%$ & $\begin{array}{l}\text { Drug Store/ } \\
\text { Pharmacy }\end{array}$ & 3 & $0,8 \%$ \\
\hline 10 & Tesco PLC & UK & 73.961 & $2,8 \%$ & $\begin{array}{l}\text { Hypermarket/ } \\
\text { Supercenter/ } \\
\text { Superstore }\end{array}$ & 8 & $20,7 \%$ \\
\hline Top 10 & & & 1.430 .353 & $6,1 \%$ & & 12,9 & $25,1 \%$ \\
\hline $\begin{array}{l}\text { Top } \\
250\end{array}$ & & & 4.530 .059 & $5,7 \%$ & & 9,5 & $23,6 \%$ \\
\hline
\end{tabular}

Source: Global power of retailing, 2019.

The previous table shows that the 10 largest trading companies use different trading formats or institutions, both classical and contemporary. The use of trade formats (institutions) by the 250 largest retail chains (as a percentage) is shown in Figure 1. 
Figure 1: Trade formats of the 250 largest retail chains

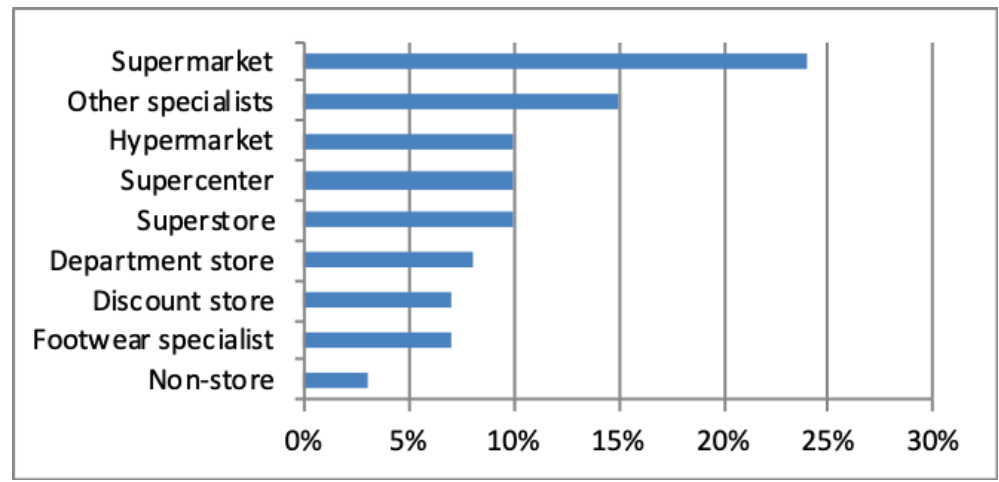

Source: Authors calculation

Figure 1 shows that supermarkets have a significant share $(24 \%)$ in the business portfolio of the largest trading companies, despite the fact that in many market economies, supermarkets are in the saturation phase of their life cycle (Ćuzović, Sokolov Mladenović \& Ćuzović, 2017). Hypermarkets (10\%), superstores (10\%), as well as discount stores show a significant share. Specifically, numerous economic factors have opened the door for increased expansion of discount stores, especially the so-called hard discount stores. These are business formats that follow an aggressive "daily low pricing" strategy with prices 20 to $30 \%$ lower than supermarket prices. They offer a limited range of highturnover products, with a small number of products and brands within each category (Saini \& Sahay, 2014). These characteristics of hard discount stores, on the one hand, and the low purchasing power of consumers with the need to buy at the lowest possible prices, on the other, are the reason why hard discount trading companies in their business portfolios report an increased growth rate in the countries where they are present. An example is Lidl, part of the German Schwarz Gruppe, which is expanding in the countries of the former SFRY. Starting its business with 15 discount stores on the Serbian market in October 2018, Lidl has reached 37 discount stores, which are currently present, and it announces further business expansion (https://kompanija.lidl.rs/).

In addition, modern and electronic forms of institutional innovation are also characteristic of trade, which is a direct consequence of the application of modern information and communication technology (Stevanovski \& Pavloska-Gjorgjieska, 2016). An illustrative example is Amazon.com, which brings together classic and contemporary trading institutions. By annual revenue, the company is today the largest electronic bookstore in the world and the seventh largest employer in the United States. Two years ago, the company introduced a new store format called AmazonGo that has no cashier or cart. Consumers enter the store, register with a mobile phone, pick up products off the shelf, and then exit without being checked. Crucially, there are systems that, thanks to artificial intelligence and computerized data processing, identify what the consumer has purchased and, upon his or her exit from the store, calculate the electronic transaction. 


\section{Research methodology and hypotesis}

Previous theoretical considerations suggest that trade is an innovation-intensive sector of the economy, especially in the institutional innovation segment. For this reason, we test the hypothesis of the importance of introducing institutional innovation for success or ranking of trading companies in the list of the most successful ones. The empirical research relates to the 250 largest trading companies, from 2012 to 2017, based on Deloitte Touche data (Global Power of Retailing 2014-2019).

Although the mathematical modelling of the trade formats on the success (ranking) of trade companies has been studied already, the main goal in this paper was to apply artificial intelligence technique, adaptive neuro-fuzzy inference system (ANFIS) (Petković et al., 2012) , for the testing of hypothesis of impact of the trade formats on the ranking of trade companies.

After the defined research sample, it is necessary to determine the data that will be subject to analysis. Since the aim is to explore the importance of trade formats (institutions) on the positioning of trade companies, for the purpose of this study, data on the number of used trade formats will be taken from the last six Global Power of Retailing reports. At the same time, according to the available report data, trade companies positioning' relative to the competition will be analysed based on their ranking in the observed reports. The number of trade formats and the number of countries represent the first and the second input for the ANFIS analysis. Rang represent the output parameter of the ANFIS network. Therefore ANFIS network should determine the ranking. The number of trade formats used by trade companies is a determinant of their position in the top 250 world trade companies. In addition to the number of used trade formats, the number of countries where a trade company operates is a statistically significant determinant of ranking among the top 250 trade companies.

\section{Research results and discussion}

As it pointed out, ANFIS method was used ANFIS network has 5 layers which perform the specific operation on the given data samples. In this study ANFIS network has two inputs which represent the number of trade formats and the number of countries. Based in the inputs, ANFIS network should estimate the ranking parameter. The main core of the ANFIS network is fuzzy inference system. The fuzzy inference system operates with fuzzy inputs. The inputs are converted in fuzzy values by membership functions.

Table 2 shows the descriptive statistics of the input and output parameters. Data in Table 2 shows that the standard deviation in respect of ranking equals the mean value, i.e. that the analysed trade companies are among the better-ranked ones (in this case, among the top 70). The mean number of countries in which they operate is 14 , but there is also a large standard deviation, so, according to this criterion, there is a large dispersion. In terms of the number of trade formats, the mean value is 3 , and standard deviation around 1 . This means that the sample includes almost an equal number of observations of those who use only one trade format and those who use two or more trade formats. Results of descriptive statistics related to the correlation coefficient between the dependent and independent variables are shown in Table 3. Table 3 show that there is no strong correlation (greater than 0.7 ) between the dependent and independent variables, but that there is certain correlation among them, which provides for the right to proceed with further research. 
Table 2: Results of descriptive statistics

\begin{tabular}{|l|l|l|l|}
\hline & Mean & Std. Deviation & N \\
\hline Ranking & 17,39 & 14,279 & 119 \\
\hline Num. of trade formats & 3,05 & 1,171 & 119 \\
\hline Number of countries & 14,36 & 10,160 & 119 \\
\hline
\end{tabular}

Source: Authors calculation

Table 3: Correlation coefficients

\begin{tabular}{|l|l|l|l|l|}
\hline \multicolumn{2}{|c|}{} & Ranking & $\begin{array}{l}\text { Num. of } \\
\text { formats }\end{array}$ & $\begin{array}{l}\text { Number of } \\
\text { countries }\end{array}$ \\
\hline \multirow{4}{*}{ Pearson Correlation } & Ranking & 1,000 &,- 541 &,- 600 \\
\cline { 2 - 5 } & Num. of trade formats &,- 541 & 1,000 &, 658 \\
\cline { 2 - 5 } & Number of countries &,- 600 &, 658 & 1,000 \\
\hline \multirow{4}{*}{ Sig. (1-tailed) } & Ranking & - &, 000 &, 000 \\
\cline { 2 - 5 } & Num. of trade formats &, 000 & - &, 000 \\
\cline { 2 - 5 } & Number of countries &, 000 &, 000 & 119 \\
\hline \multirow{3}{*}{ N } & Ranking & 119 & 119 & 119 \\
\cline { 2 - 5 } & Num. of trade formats & 119 & 119 & 119 \\
\cline { 2 - 5 } & Number of countries & 119 & 119 & 19 \\
\hline
\end{tabular}

\section{Source: Authors calculation}

Figure 2 shows the ANFIS prediction of ranking based on number of trade formats and number of countries. Statistical indicators for the ANFIS model are: coefficient of determination of the prediction is 0.465 , Pearson coefficient is 0.6819 and the root means square error (RMSE) is 10.4. This indicates that the constructed ANFIS model, which includes the number of trade formats used and the number of countries where a trade company operates explains almost 50 per cent of the variance in the position in the ranking (ranking among the top 250 trade companies).

Standard multiple regression analysis gives the following results: coefficient of determination of the prediction is 0.288 , Pearson coefficient is 0.537 and the root means square error (RMSE) is 12.154. This indicates that the constructed multiple regression model, which includes the number of trade formats used and the number of countries where a trade company operates explains almost 30 per cent of the variance in the position in the ranking (ranking among the top 250 trade companies).

One can conclude that the ANFIS outperforms the standard regression analysis. Figure 3 shows the ANFIS prediction surface based on the two given inputs. 
Figure 2: ANFIS prediction of ranking

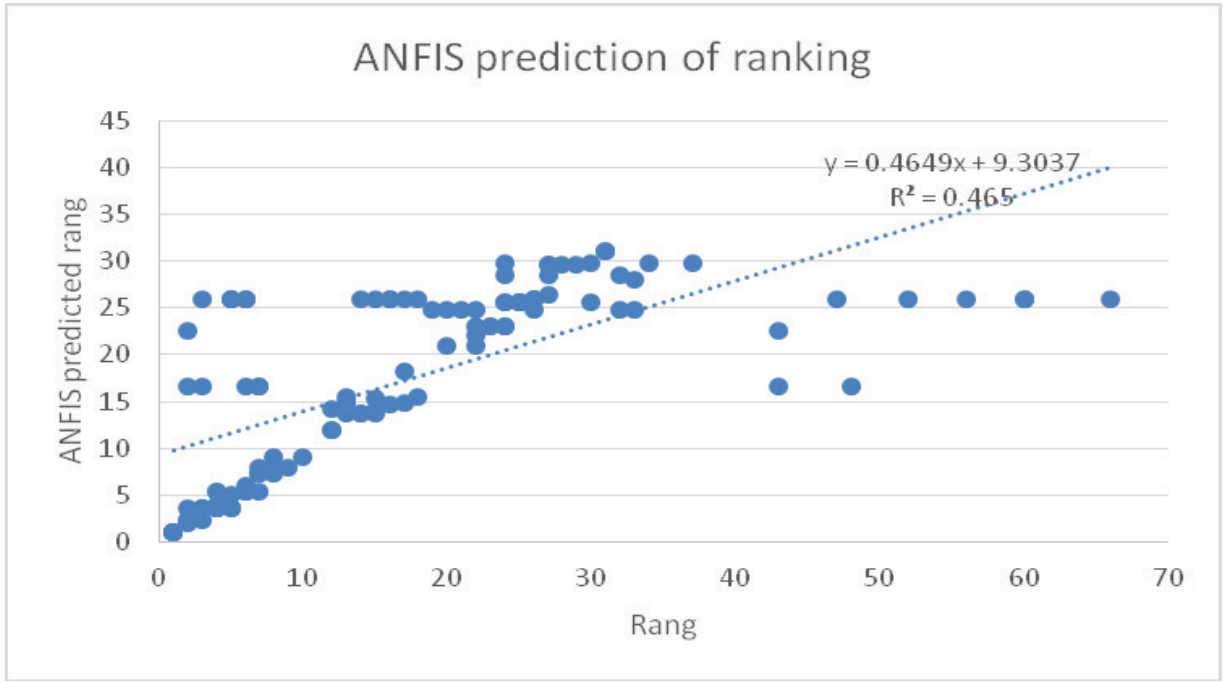

Source: Author

Figure 3: ANFIS prediction of ranking based on the two given inputs

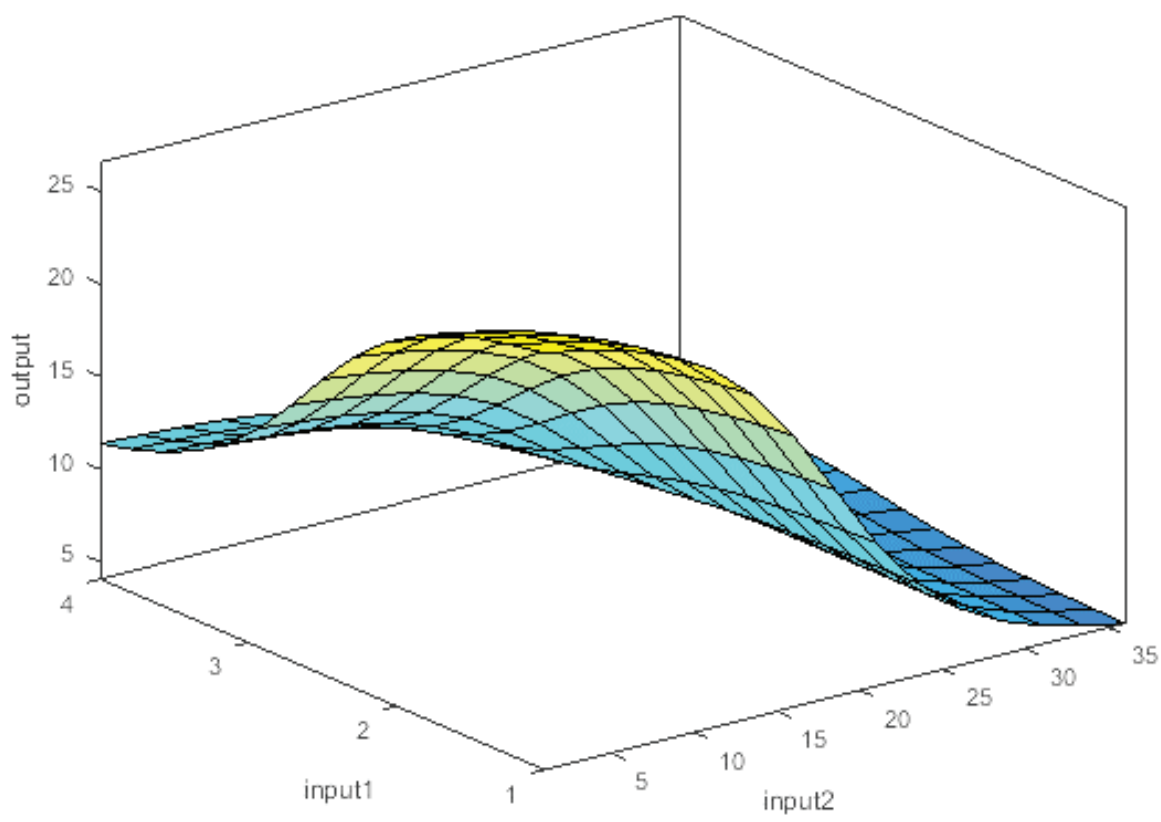

Source: Author 


\section{Conclusion}

Numerous and varied theoretical and practical studies in the field of trade and trade management show that innovation in trade can be divided into institutional, functional and technological. In this regard, seen in the long run, institutional innovation is of the utmost importance for trade. It gets its expressive form through a continuous process of development, saturation and disappearance of one group of trading institutions and the emergence of another, with different forms and methods of conducting trade activities. The achieved level of institutional innovation in trade is largely conditioned by socio-economic factors, so that the market developed countries record more intensive application of institutional innovation in trade, in comparison with less developed countries. One can make certain generalization, as well as the analysis of the principles in the development of institutional innovation in trade based on different theories and concepts, which was the research subject in the first part of the paper. The second part of the paper analyzed the application of institutional innovation by the 250 largest trading companies, according to the latest report by Deloitte Touche. The analysis showed that supermarkets and hypermarkets dominate the business portfolio of the largest trading companies, with a growing tendency for discount stores and e-shops. The third part of the paper described empirical research on the basis of available data sources. The database consisted of six annual reports (2012-2017) ranking the 250 largest trading companies in the world. The ANFIS method was applied to test the hypothesis of the importance of institutional innovation for ranking trading companies in the list of the most successful ones. The research results showed that the introduction of institutional innovation in the business portfolio of a trading company improves its ranking in the list of the most successful trading companies.

\section{References}

Šumpeter, J.A. (1950). Capitalism, Socialism and Democracy. New York: Harper Bros.

Sokolov Mladenović, S. \& Vukojević, V. (2019). Innovation as a driver of modern retail. Facta Universitatis, 16 (2), 171-182. https://doi.org/10.22190/FUEO1902171S

Gilbert, D. (2003). Retail Marketing Management, Pearson Education Limited, Harlow, England.

Levy, M., Weitz, B.A. \& Grewal, D. (2013). Retailing Management. New York: McGrawHill.

Picot-Coupey, K., Viviani, J-L. \& Paul, A. (2018). Determinants of retail store network expansion via shop-inshops. International Journal of Retail \& Distribution Management, 46 (10), 915-943. https://doi.org/10.1108/IJRDM-08-2016-0139

Reynolds, J., Howard, E., Cuthbertson, C. \& Hristov, L. (2007). Perspectives on retail format innovation: relating theory and practice. International Journal of Retail and Distribution Management, 35 (8), 647-660. DOI: 10.1108/09590550710758630

Hristov, L. (2007). Innovating as a retailer: executive perspectives. The European Retail Digest, 2 (55), 7-16. 
Lovreta, S., Končar, J., Petković, G., Bogetić, Z. \& Stojković, D. (2019). Kanali marketinga. Beograd: Centar za izdavačku delatnost Ekonomskog fakulteta.

Ćuzović, S., Sokolov Mladenović, S. \& Ćuzović, Đ. (2019). The impact of social and cultural factors on success of trade internationalization. Business Excellence, 13 (1), 57-76. https://doi.org/10.22598/pi-be/2019.13.1.57

Ćuzović, S., Sokolov Mladenović, S., Ćuzović, Đ. (2017). Impact of Retail Formats on the Development of Food Retailing. Entrepreneurial Business and Economics Review, 5 (1), 11-26. https://doi.org/10.15678/EBER.2017.050101

Saini, G.K. \& Sahay, A. (2014). Comparing retail formats in an emerging market. Journal of Indian Business Research, 6 (1), 48-69. https://doi.org/10.1108/JIBR-03-20130026

https://kompanija.lidl.rs/

Global Power of Retailing 2014-2019. Retrieved January 20, 2020 from: https://www2. deloitte.com/rs/en/pages/consumer-business/articles/global-powers-of-retailing.html

Petković, D., Issa, M., Pavlović, N.D., Zentner, L. \& Ćojbašić, Ž. (2012). Adaptive neuro fuzzy controller for adaptive compliant robotic gripper. Expert Systems with Applications, 39, 13295-13304. https://doi.org/10.1016/j.eswa.2012.05.072

Global power of retailing 2019. Retrieved January 20, 2020 from: https://www2.deloitte. $\mathrm{com} /$ content/dam/Deloitte/global/Documents/Consumer-Business/cons-globalpowers-retailing-2019.pdf

Morgan, E. (2015). 'Plan A': Analysing Business Model Innovation for Sustainable Consumption in Mass-Market Clothes Retailing. Journal of Corporate Citizenship. (57), 73-98. https://doi.org/10.9774/GLEAF.4700.2015.ma.00007

Pantano, E., Priporas, C-V., Sorace, S. \& Iazzolino, G. (2017). Does innovationorientation lead to retail industry growth? Empirical evidence from patent analysis. Journal of Retailing and Consumer Services, 34, 88-94. https://doi: 10.1016/j. jretconser.2016.10.001

Pantano, E. (2016). Benefits and risks associated with time choice of innovating in retail settings. International Journal of Retail \& Distribution Management, 44 (1), 58-70. https://doi.org/10.1108/IJRDM-03-2015-0047

Hasanov, A. (2019). Relevant economic factors affecting franchise operations in the services and trade sectors. International Review, (3-4), 38-49. https://doi: $10.5937 /$ intrev $1903038 \mathrm{H}$

Hristov, L. \& Reynolds, J. (2015). Perceptions and practices of innovation in retailing, challenges ofdefinition and measurement. International Journal of Retail\&Distribution Management, 43 (2), 126-147. https://doi.org/10.1108/IJRDM-09-2012-0079

Evans, J.R. (2011). Retailing in perspective: the past is a prologue to the future. International Review of Retail, Distribution and Consumer Research, 21 (1), 1-31. https://doi.org/10.1080/09593969.2011.537817

Vojvodić, K. (2019). Brick-and-mortar retailers: Becoming smarter with innovative technologies. Strategic Management, 24(2), 3-11.https://doi: 10.5937/ StraMan1902003V 
Cao, L. (2014). Business model transformation in moving to a cross-channel retail strategy: a case study. International Journal of Electronic Commerce, 18 (4), 69-95. https://doi. org/10.2753/JEC1086-4415180403

Stevanovski, M. \& Pavloska-Gjorgjieska, D. (2016). Electronic Commerce as an Integral Part of the Digital Economy with emphasis on its application in the Republic of Macedonia. Ekonomika, 62 (1), 113-124. https://doi:10.5937/ekonomika1601113S 